\section{Exploring the relationships between gamification and motivational needs in technology design}

\author{
Jian Tang
}

School of Information, Central University of Finance and Economics, Beiïn, China, and

Ping Zhang

School of Information Studies, Syracuse University, Syracuse, New York, USA
Technology design

Received 26 September 2018 Revised 14 October 2018 Accepted 15 October 2018

\begin{abstract}
Purpose - Drawing upon the motivational affordance theory, this paper aims to investigate how gamification design and human motivational needs are associated in extant literature.

Design/methodology/approach - The authors conducted a literature analysis of 60 journal articles that studied motivational influences of gamification in information technology design. Content analysis was used to identify game design features and motivation variables studied in prior literature, and correspondence analysis was used to show the co-occurrence of game design features and basic motivational needs.
\end{abstract}

Findings - The results showed that four types of game design features and eight basic motivational needs are studied in this pool of literature. Correspondence analysis indicates some interesting associations between game design features and basic human needs.

Research limitations/implications - This research used a motivational affordance perspective to interpret the impact of game design features and suggested directions for future investigations. It is limited due to its sample size and considered as an exploratory study.

Practical implications - This research provided suggestions for technology designers that game design features vary in their motivational influence, and therefore, game design features should be used accordingly to meet users' motivational needs.

(C) Jian Tang and Ping Zhang. Published in International Journal of Crowd Science. Published by Emerald Publishing Limited. This article is published under the Creative Commons Attribution (CC BY 4.0) licence. Anyone may reproduce, distribute, translate and create derivative works of this article (for both commercial and non-commercial purposes), subject to full attribution to the original publication and authors. The full terms of this licence may be seen at http://creativecommons.org/ licences/by/4.0/legalcode

This research is supported by National Key Research and Development Plan of China (2017YFB1400100) and the Ministry of Education, Humanities and Social Sciences Council in China (grant number 18YJCZH160).

Erratum: It has been brought to the attention of the publisher that Jian Tang and Ping Zhang (2018) "Exploring the relationships between gamification and motivational needs in technology design", published in the International Journal of Crowd Science, https://doi.org/10.1108/IJCS-09-2018-0025 is not the final version of the manuscript and was published due to a production error. Emerald and its typesetters sincerely apologize to the authors for any inconvenience caused. The final version of the manuscript has now been published in its place and contains revised figures and expands upon several sections.

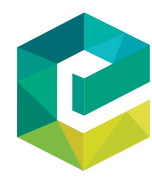

International Journal of Crowd Science

Vol. 3 No. 1, 2019 pp. $87-103$

Emerald Publishing Limited 2398-729 


\section{IJCS 3,1}

Originality/value - This research is one of initial studies which explored the association between game design features and basic motivational needs. The findings of this study provide the groundwork for guidelines and strategies to facilitate motivational design in information technology.

Keywords Gamification, Human-computer interaction, Basic human needs, Motivational affordances

Paper type Research paper

\section{Introduction}

Motivation refers to what gives behavior its energy and direction (Ryan and Deci, 2000). In information technology design, a motivational perspective has become increasingly popular and uncovered the drive for technology use (Zhang, 2008a). To understand the underlying mechanism of user behavior in technology interaction, researchers who are interested in the motivational perspective have raised questions such as "why do people initiate, continue, stop, or avoid using technology," "why do such behaviors vary in intensity" and "how can our understandings of people's behaviors and their intensity help us design desirable technology that people want to use." (Zhang, 2008a). Therefore, knowing how to effectively motivate users to adopt and continue using information technology has become a critical issue for researchers and practitioners. In recent years, gamification design, an approach that integrates non-game activities with play to afford similar experiences as games do (Huotari and Hamari, 2017), has been used to engage users in many serious contexts, such as information systems (Liu et al., 2017), marketing (Huotari and Hamari, 2017), education (Hanus and Fox, 2015) and health care (Hamari and Koivisto, 2015b).

Despite an increasing attention from researchers and practitioners, researchers have identified inconsistent impact of using gamification design when influencing user psychological states (Morschheuser et al., 2017). Prior research has presented conflicting findings regarding the effects of gamification design. For instance, quantified measurements such as points, leaderboards and levels are found to have positive effects on user participation (Halan et al., 2010), though researchers are also concerned that these game elements may only increase participants' extrinsic motivation in the short-term period, with diminishing effects in the long run (Lee et al., 2013). Mekler et al. (2017) found that goal metrics such as points, levels and leaderboards mostly function as external incentives. Research has even found that badges and leaderboards had negative impacts on motivation and student performance in an educational project (Hanus and Fox, 2015). Leaderboards may demotivate low-ranked participants and lead to possible negative effects on overall outcomes (Ipeirotis and Gabrilovich, 2015; Massung et al., 2013; Preist et al., 2014).

One possible reason for such contradictory finding is that many studies do not isolate the effects of individual game elements, and it is therefore impossible to assess to what extent each game element explained the variance of user motivation and performance (Morschheuser et al., 2017; Peng et al., 2012). More importantly, findings from prior studies showed that it is still unclear to what extent the extant literature on gamification takes on a motivational perspective and what are motivational mechanisms of game design elements. In particular, it is still uncertain how to interpret the motivational effects of gamification design and what the motivational paths of game design features are. Given that gamification has become such a trendy approach in technology design, understanding the motivational path of gamification design would make future gamification design more effective and efficient.

As a first step toward that understanding, we conducted a literature analysis of published papers that focus on gamification and motivation that relates to technology design or evaluation. Specifically, we draw upon the motivational affordances theory to 
understand the motivational influences of gamification design. This analysis focuses on game design features and their potential relationships with basic human needs. Our investigation is guided by two research questions:

RQ1. To what extent game design features are linked to basic human needs?
$R Q 2$. What are the potentials of gamification design to motivate users through
satisfying their basic needs?

RQ1. To what extent game design features are linked to basic human needs?
$R Q 2$. What are the potentials of gamification design to motivate users through
satisfying their basic needs?

RQ1. To what extent game design features are linked to basic human needs?
$R Q 2$. What are the potentials of gamification design to motivate users through
satisfying their basic needs? (1)

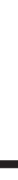

\section{Related work}

\subsection{Gamification}

Gamification is a design approach that introduces game elements into non-game contexts to attract participants and create gameful experiences (Hamari et al., 2014). Researchers in information systems (IS) field have shown a long interest in gamification design, though not always using the term "gamification." IS researchers have investigated the impact of games, play design, rewards and scores (Broer and Poeppelbuss, 2013). These prior attempts showcased the importance of gameful design and its profound effects on technology use (Schlagenhaufer and Amberg, 2015) and identified the potentiality of using gamification design to make repetitive tasks more fun and enjoyable (Flatla et al., 2011).

Among few conceptualizations of gamification, Liu et al. (2017) suggested that gamification design could be categorized into two broad categories, gamification objects and gamification mechanics. Gamification objects refer to visual or non-visual digital objects that form building blocks of gamification systems. Examples of gamification objects include graphics, audio clips, avatars, virtual items, artificial characters, storylines, badges and leaderboards. Gamification mechanics is a higher level of design that is built with game artifacts with play patterns and dynamics, such as level system, point system, quests, competition, and collaboration, in-game economy and social networking systems. These two conceptual levels of gamification design informed a structured view of gamification design, and the framework proposed by Liu et al. (2017) takes a further step to illustrate the motivational influences of these two categories of gamification design. Gamification objects are fundamental components of gamification design and have been investigated in many prior studies (Mekler. et al., 2017; Landers and Armstrong, 2017). To figure out the motivational mechanism of gamification design, it is important to understand the association between gamification objects and their motivational effects. In this research, we attempted to investigate the impact of gamification design at the level of gamification objects, which is at times referred to as game design features. Therefore, in the following paper, terms gamification objects and game design features will be used interchangeably.

\subsection{Motivational affordance theory}

Several researchers attempted to undertake the perspective of motivational affordances to investigate the effects of gamification design, and the term "gamification affordance" is used to indicate the motivational effect of individual game elements (Morschheuser et al., 2017). However, according to the motivational affordance theory (MAT) (Zhang, 2008a), motivational affordances indicate the action possibilities supported by information technology to satisfy basic needs. So gamification affordances should not be equivalent to specific game elements, which, however, only represent object features that are implemented in gamified technology design. Meanwhile, we admit the importance of using the notion of motivational affordances to interpret the effects of gamification design. 
IJCS
3,1

90

Motivational affordances refer to the action possibilities perceived by users of an information and communication technology (ICT) to satisfy their internal motives (Zhang, 2008a; Zhang, 2008b). MAT posits that technology can be designed in a way that affords possibilities to satisfy basic human needs. MAT is rooted in motivational theories, which speculate the sources and roles of motivation on behavior. There are two types of sources of motivation: external events and internal motives (Reeve, 2005). External events are environmental incentives that have the capacity to energize and direct behavior, such as learning to earn monetary rewards (Ryan and Deci, 2000). On the other hand, an internal motive is an internal process that energizes and directs behaviors, such as learning for the sake of enjoying it (Ryan and Deci, 2000). Internal motives serve the organism by generating wants, desires and strivings that motivate whatever behaviors are necessary for the sake of well-being and growth.

Human basic needs, including physiological needs, psychological needs, social needs, cognitions and emotions, should be considered to enhance motivational aspect of technology design (Zhang, 2008b). Physiological needs relate to the working mechanism of biological systems, which is inherently associated with the strivings of human nature and healthy development. Psychological needs are generated from one's desire to pursue interaction with the environment, creating practices that promote psychological vitality, well-being and growth. Examples of such needs include autonomy, competence and relatedness. Social needs relate to one's socialization history, reflecting the activated emotional response to a need-relevant incentives, such as desire for power. Cognitions refer to mental events such as beliefs, expectations and the self-concept. Cognitive sources of motivation revolve around a person's ways of thinking. Emotions are shortlived, subjective phenomena that orchestrate how we react adaptively to the important events in our lives. Based on these typical categories of sources of motivation, eight basic needs were identified to represent the fundamental drive of human behavior and were argued to be granted substantial research attention in information technology design (Zhang, 2008b; Zhang, 2008a). Table I summarizes the eight basic human needs identified in the MAT.

According to the MAT (Zhang, 2008a), motivational affordances indicate action possibilities supported by information technology to satisfy basic needs. It is important to note that motivational affordances are not equivalent to specific design objects and actually indicate some relational attributes between design objects and human motivational needs. The extant literature shows a gap regarding how game design features are associated with

\begin{tabular}{|c|c|}
\hline Basic needs & Descriptions \\
\hline Autonomy & Need for choice in initiating and regulating one's behavior \\
\hline Self & $\begin{array}{l}\text { Need for defining/creating self and self-image, relating the self to society and discovering } \\
\text { and developing personal potentials }\end{array}$ \\
\hline Competence & Need to master challenges that are developmentally appropriate \\
\hline Achievement & $\begin{array}{l}\text { Desire to do well relative to a standard of excellence that encompasses competitions with a } \\
\text { task, with the self and against others }\end{array}$ \\
\hline Leadership & $\begin{array}{l}\text { Desire to make physical or social world to conform to one's image/plan; desire to impact or } \\
\text { control over others or the world }\end{array}$ \\
\hline Followership & Desire to be influenced by others, to follow others \\
\hline Relatedness & Desire to belong \\
\hline $\begin{array}{l}\text { Affect and } \\
\text { emotion }\end{array}$ & $\begin{array}{l}\text { Induced affective states arising as reactions to important stimuli; favorable reacts to } \\
\text { stimuli as a natural selection process; sustain desired emotions via cognitive process }\end{array}$ \\
\hline
\end{tabular}

Table I.

Basic human needs emotion 
human motivation, and the lens of motivation affordances provides a niche to interpret the effects of gamification design.

\section{Research methodology}

\subsection{Paper selection}

To gain an understanding of how extant literature addresses the motivational impact of gamification design in the context of technology design, we conducted a review of gamification studies reported in English that have a motivational component, an information technology aspect and a design approach or empirical evaluations and may have broad applications in various domains. There are several steps leading to the pool of papers to be selected for this study.

In Step 1, we conducted a literature search with the phrase «gamif* AND motiv*» in six databases in November 2017. To ensure the relevance of search results, we limited the fields of search to title, abstract and keywords. The search returned the following results: web of Science 765 hits, Scopus 1,120 hits, Science Direct 98 hits, ProQuest 71 hits and JSTOR 5 hits. As the Association of Information Systems e-library does not allow users to set search fields to include title, abstract and keywords altogether, we did the same phrase search in the full-text, which yielded 320 hits.

In Step 2, non-English journals or articles, trade magazine articles, conference proceeding papers and editorial, short demo, opinion or pop educational papers were removed to ensure that the selected articles report complete research and have sufficient details.

In Step 3, additional selection criteria were applied to the papers from Step 2 so that the collection of selected articles met the research purpose. An article was removed if it fit one or more following conditions:

- has no ICT component (a paper should be about designing or evaluating an ICTbased gamification or gamification using ICT);

- is not about gamification (might just have a mere mentioning of it);

- is not about the design or evaluation (with real subjects, and not just preliminary empirical study) of a gamification system/application;

- is a design paper without empirical evaluation or theory-driven design guidelines;

- is a conceptual paper with no specific design or evaluation of a gamification system/ application;

- is a review or synthesis of gamification studies or development;

- is a pure qualitative study (e.g., focus group, case study and interview); and

- is impossible to identify motivational states or drives of participants (e.g. young children 30-50 months old and second-year primary school students).

\subsection{Paper analysis}

After removing papers that did not meet the filtering criteria, only 60 empirical studies were kept for the following literature analysis. Gamification designs share essential features that make non-game activities "gameful." Based on the structured view of gamification design (Liu et al., 2017), gamification mechanics are a level of design that build on a series of gamification objects, which represents more fundamental design blocks in a gamified technology. To understand the fundamental building blocks of gamification in ICT design, we try to identify specific game design features and attempt to classify them into categories that may have practical meanings and functions. 
IJCS

3,1

We also analyzed motivational related variables, constructs and themes to assess to what extent the extant literature undertakes a basic needs perspective to understand motivational influences of gamification design. Only a few of the 60 articles addressed the eight basic needs directly, either as core research variables or themes. For example, competence is directly studied as a variable in Nelson et al. (2016); needs for competence, relatedness and autonomy have been directly studied by Tan and Hew (2016).

For the majority of the 60 papers, basic needs were not the foci of the studies. Yet, each of these studies would consider some motivational variables (see paper selection criteria). A careful examination of the wordings of the measures for motivational variables may reveal that some basic needs are being touched upon, even if not consciously, thoroughly or rigorously. For example, in Suh et al. (2017), the measurements for four facets of flow experience and three facets of aesthetic experience touch upon the following five basic needs: autonomy, self, competence, achievement, and affect and emotion. Therefore, two researchers recorded motivation-related variables studied in the collected and then used Table I as a guiding codebook to identify basic needs from each of the 60 papers. Two researchers independently coded basic needs, using motivational affordances theory as a guide framework. The initial inter-rater agreement was 83 per cent, and after discussions, the agreement reached 100 per cent.

\section{Results}

In this section, we present descriptive and direct observations from the literature analysis of the 60 papers. The 60 papers were published in 36 different journals. Among these journals, Computer in Human Behavior published 16 papers, Computers and Education published 6, four journals published 2 papers each and the rest of the 30 journals published 1 article each. The publication years range from 2013 to 2018, with 1 paper in each of 2013 and 2018, 5 in 2014, 14 in 2015, 17 in 2016 and 22 in 2017. The frequency distribution shows a sharp increase in the number of publications on this topic in recent years.

The collected articles have addressed a variety of application domains. The most studied application domain is education and learning (33), followed by marketing and e-commerce (9) and health care (7). Other domains include knowledge management, crowdsourcing, human resource management, social media, manufacturing, tourism and citizen science. The broad distribution of domains shows that researchers from various disciplines showed interest in implementing gamification design in technology design to enhance user motivation.

\subsection{Findings on game design features}

Specific gamification objects were found in each of the 60 articles. Two researchers independently reviewed the articles and recorded original terms used in the literature. Overall, 147 game design features were identified in this literature collection. Table II shows the frequencies of commonly studied game design features. Badges/trophies, leaderboards and points are the three top game features that have been studied in this pool of literature, followed by levels, avatar and virtual item.

The analysis revealed a list of game features as shown in Table II, yet it is notable that not all these features influence cognitive, sensory or function experiences of users in the same way. Upon careful examination of these features, the following four types of features are emerged: 


\begin{tabular}{|c|c|c|c|c|}
\hline Features & Papers & Frequency & $(\%)$ & $\begin{array}{r}\text { Technology } \\
\text { design }\end{array}$ \\
\hline \multirow[t]{2}{*}{$\begin{array}{l}\text { Badges/ } \\
\text { trophies }\end{array}$} & $\begin{array}{l}\text { (Aydin, 2018; Alabbasi, 2017; Bittner and Shipper, 2014; Borras-Gene } \\
\text { et al., 2016; Ding et al., 2017; Hakulinen } \text { et al., 2015; Hamari and } \\
\text { Koivisto, 2015a, Su and Cheng, 2015; Koivisto and Hamari, 2014; } \\
\text { Malas and Hamtini, 2016; Cheong et al., 2014; Hamari, 2013; Auvinen } \\
\text { et al., 2015; Wang et al., 2016; Sailer et al., 2017; Albuquerque } \text { et al., } \\
\text { 2017; Halloluwa et al., 2016; Hew et al., 2016; Frost et al., 2015; Kwon } \\
\text { et al., 2015; Hamari and Koivisto, 2015b, Fajiculay et al., 2017; }\end{array}$ & \multirow[t]{2}{*}{30} & \multirow[t]{2}{*}{20} & \multirow[t]{3}{*}{93} \\
\hline & $\begin{array}{l}\text { Buckley and Doyle, 2017; Sigala, 2015b, Gonzalez et al., 2016; Browne } \\
\text { et al., 2014; Aydin, 2015; Suh et al., 2017) }\end{array}$ & & & \\
\hline Leaderboards & $\begin{array}{l}\text { (Zarzycka-Piskorz, 2016; Aydin, 2018; Yang et al., 2017; Alabbasi, } \\
\text { 2017; Bittner and Shipper, 2014; Hamzah et al., 2015a, Landers and } \\
\text { Armstrong, 2017; Rodrigues et al., 2017; Su and Cheng, 2015; Malas } \\
\text { and Hamtini, 2016; Mekler. et al., 2017; Wang et al., 2016; Sailer } \text { et al., } \\
\text { 2017; Albuquerque et al., 2017; Nebel et al., 2016; Tan and Hew, 2016; } \\
\text { laremenko, 2017; Chen et al., 2016; Buckley and Doyle, 2017; } \\
\text { Gonzalez et al., 2016; Fotaris } \text { et al., 2016; Aydin, 2015; Suh } \text { et al., 2017; } \\
\text { Suh and Wagner, 2017) }\end{array}$ & 24 & 16 & \\
\hline Points & $\begin{array}{l}\text { (Nebel et al., 2017; Aydin, 2018; Alabbasi, 2017; Bittner and Shipper, } \\
\text { 2014; Prestopnik and Tang, 2015; Hamari and Koivisto, 2015a, } \\
\text { Rodrigues et al., 2017; Koivisto and Hamari, 2014; Song et al., 2017; } \\
\text { Boendermaker et al., 2015; Albuquerque et al., 2017; Su, 2016; } \\
\text { Morillas Barrio et al., 2016; Chen } \text { et al., 2016; Buckley and Doyle, } \\
\text { 2017; Gonzalez et al.,2016; Fotaris et al., 2016; Suh } \text { et al., 2017) }\end{array}$ & 19 & 13 & \\
\hline Levels & $\begin{array}{l}\text { (Hamari and Koivisto, 2015a, Koivisto and Hamari, 2014; Malas and } \\
\text { Hamtini, 2016; Luu and Narayan, 2017; Boendermaker } \text { et al., 2015; } \\
\text { Nebel et al., 2016; Browne et al., 2014; Suh and Wagner, 2017; Suh } \\
\text { et al., 2017) }\end{array}$ & 9 & 6 & \\
\hline Avatar & $\begin{array}{l}\text { (Rodrigues et al., 2017; Rodrigues et al., 2016b, Kaczmarek et al., } \\
\text { 2017; Rodrigues et al., 2016a, Sailer et al., 2017; Albuquerque et al., } \\
\text { 2017; Su, 2016; Buckley and Doyle, 2017) }\end{array}$ & 8 & 5 & \\
\hline Storyline & $\begin{array}{l}\text { (Prestopnik and Tang, 2015; Boendermaker et al., 2015; Sailer et al., } \\
\text { 2017; Pitura and Chmielarz, 2017; Su, 2016) }\end{array}$ & 5 & 3 & \\
\hline Virtual item & $\begin{array}{l}\text { (Santhanam et al., 2016; Su, 2017; Snow et al., 2015; Sigala, 2015b, } \\
\text { Aydin, 2015) }\end{array}$ & 5 & 3 & \\
\hline Progress & $\begin{array}{l}\text { (Siemens et al., 2015; Nelson et al., 2016; Buckley and Doyle, 2017; } \\
\text { Fotaris et al., 2016) }\end{array}$ & 4 & 3 & \\
\hline Rewards & $\begin{array}{l}\text { (Hamzah et al., 2015a, Kim and Ahn, 2017; Tan and Hew, 2016; Suh } \\
\text { et al., 2017) }\end{array}$ & 4 & 3 & \\
\hline Character & (Su, 2017; Kaczmarek et al., 2017; Su, 2016) & 3 & 2 & \\
\hline Feedback & (Zarzycka-Piskorz, 2016; Alabbasi, 2017; Gonzalez et al., 2016) & 3 & 2 & \\
\hline Role-play & (Su, 2017; Luu and Narayan, 2017; Su, 2016) & 3 & 2 & \\
\hline Team & (Rodrigues et al., 2016b; Rodrigues et al., 2016a, Sailer et al., 2017) & 3 & 2 & \\
\hline Missions & (Su and Cheng, 2015; Luu and Narayan, 2017) & 2 & 1 & \\
\hline Countdown & (Su, 2016; Gonzalez et al., 2016) & 2 & 1 & \\
\hline Challenges & (Adukaite et al., 2017; Gonzalez et al., 2016) & 2 & 1 & \\
\hline Combat & (Kaczmarek et al., 2017; Buckley and Doyle, 2017) & 2 & 1 & \\
\hline Others & $\begin{array}{l}\text { (Ding et al., 2017; Pe-Than et al., 2014; Santhanam et al., 2016; } \\
\text { Rodrigues et al., 2017; Boendermaker } \text { et al., 2015; Sailer et al., 2017; } \\
\text { Chen et al., 2016; Buckley and Doyle, 2017; Browne et al., 2014; } \\
\text { Aydin, 2015, Hamzah } \text { et al.,2015b) }\end{array}$ & 19 & 13 & \\
\hline $\begin{array}{l}\text { Note: Game de } \\
\text { and animated c }\end{array}$ & $\begin{array}{l}\text { sign features that only appeared once were categorized as "others", su } \\
\text { ontents }\end{array}$ & s applau & usic & $\begin{array}{r}\text { Table II. } \\
\text { Game design features } \\
\text { and frequencies }\end{array}$ \\
\hline
\end{tabular}


IJCS

3,1

94

(1) Type 1: It indicates performance status by providing quantitative measurements. Examples include badges, points, scores, difficulty levels, prizes, status bars, etc.

(2) Type 2: It engages players deeper into the essence and meaningfulness of the games. Examples include storylines, mission, character building, avatars, profile, role-play, etc.

(3) Type 3: It indicates social significance and influence. Examples include leaderboards, collaborative, social points, social media sharing, likes, group forming, team building, team scores, sharing badges, etc.

(4) Type 4: It enhances the quality of experience but non-functional, thus not essential. Examples include animation, music, sound, voice, graphics, appearance customization, etc.

Therefore, game design features of each article were coded into one or more of the four types. The descriptive analysis shows that Type 1 is the most studied feature and covered in 53 papers, followed by Type 3, which is studied by 40 papers. Type 2 is studied by 31 papers, and Type 4 is studied by 4 papers. The results also show that a single paper is usually investigated more than one type of game design features. Among the 60 papers, 2 papers covered all four types in their studies, 18 papers covered three types, 26 papers covered two types and only 14 papers focused on one type of game design features. The most studied Type 1 feature is badge/trophies. Other examples of Type 1 features are level, score, point, trophy, prize, virtual currency, title, activity count, performance graph, progress bar, status bar, positive feedback, time limit, reward and percentage. The most studied Type 2 feature is avatar. Other Type 2 features are character, avatar, story line, virtual items, challenge, mission, profile, quest, goal and walk-away option. For Type 3 , the most popular feature is leaderboard. Other examples include collaborative competition, social point, social network, social media sharing, team, teammate and virtual room for socializing. There are only four papers on Type 4 with the following features: animation, music, applause, sound, voice, graphics, visualization and customization (for color, music and appearance).

\subsection{Findings on basic needs}

Basic needs are identified from variables, constructs or core themes discussed by the authors of collected literature. Collectively, the 60 papers touched upon all the eight basic needs in Table I, which shows that basic needs are either intentionally or unconsciously discussed and used by researchers when interpreting the impact of gamification design. However, our results also show that some needs, such as affect and emotion, were covered more extensively than others. Specifically, affect and emotion was studied by 37 papers, followed by competence (32 papers), relatedness (28 papers), achievement (25 papers), autonomy (17 papers), leadership (6 papers), followership (6 papers) and self (5 papers). A further examination of these frequencies indicate that most papers covered more than one basic needs. For instance, Pe-Than et al. (2014) and Kwon et al. (2015) covered six basic needs. Five papers covered five basic needs in their research (Sailer et al., 2017; Hamari and Koivisto, 2015a; Sigala, 2015a, Frost et al., 2015; Siemens et al., 2015). Furthermore, 10 papers covered four basic needs, 12 papers studied three basic needs, 14 papers investigated two basic needs and 15 papers focused on one basic needs. Two papers, however, did not examine any basic needs. The frequencies show that a majority of extant literature studied some aspects of basic human needs. 


\subsection{Correspondence analysis}

The descriptive analysis in previous sections provides an overview of game design features and basic needs identified in the collected literature. Correspondence analysis is a method applied to reveal additional insights in qualitative analysis results (Hoffman and Franke, 1986). It is an exploratory technique that displays contingency tables as points in dual, lowdimensional vector spaces (Greenacre, 1984) and provides a direct visualization of relationships among categorical variables (Glynn, 2012; Remenyi, 1992). The maximum number of dimensions needs to represent the raw data table is equal to one less than the smaller of the number of rows or columns of contingency table (Hair et al., 2006). Inertia (eigenvales) is used to assess the degree of explained variable in correspondence analysis, and usually a rule of thumb is that dimensions with inertia greater than 0.20 should be included in the analysis (Hair et al., 2006). Correspondence analysis is especially helpful to analyze contingency tables with multilevel category variables and therefore is an appropriate technique to present associations between categories of qualitative analysis codes. In this research, we conducted correspondence analysis to provide additional insights in the relationships between game design features and basic needs. It is important to note that the goal of correspondence analysis is not to validate significant relationships among categorical variables but to illustrate the co-occurrences among the variables.

Table III summarizes the co-occurrence between game design features and basic needs. For example, autonomy and Type 2 are co-studied 16 times. Leadership or followership is never co-studied with Type 4 in the 60 selected papers.

We conducted the correspondence analysis with package ca from $\mathrm{R}$ for windows 3.4.3 ( $\mathrm{R}$ Development Core Team, 2012). According to the results from the correspondence analysis, the first dimension explained 76 per cent of the variance, and the second dimension explained 17 per cent. These two dimensions explained 93 per cent of the variance, so the perceptual map (Figure 1) is drawn along these two dimensions.

Figure 1 shows four types of game design features in four quadrants, which are distinctive from one another and are surrounded by the eight basic needs. The distance between game design feature codes (GType1-4) and eight basic needs shows their cooccurrence associations. When they are closer, it means they are more likely to co-occur with each other in the collected articles. Type 1 and Type 2 are closer with each other than the other two types of game design features, indicating that these game design features are frequently studied together. Type 1 co-occurred more with autonomy, leadership and achievement. Type 2 is closely associated with affect and emotion and competence. Type 3 of game design features, which allows social interaction and awareness, co-occur more with relatedness and followership needs. Type 4 of game design features, which make the game design fancier but not with additional functions, co-occur more with the need of self needs.

\begin{tabular}{lcccrr}
\hline Basic needs & GType1 & GType2 & GType3 & GType4 & \\
\hline Autonomy & 16 & 9 & 12 & 1 & \\
Self & 5 & 4 & 5 & 1 & Table III. \\
Competence & 28 & 18 & 22 & 1 & Co-Occurrence \\
Achievement & 23 & 13 & 15 & 0 & between game \\
Leadership & 6 & 2 & 4 & 1 & feature types and \\
Followership & 6 & 2 & 23 & 4 & basic needs \\
Relatedness & 25 & 20 & 24 & & \\
Affect and emotion & 32 & & &
\end{tabular}




\section{IJCS \\ 3,1}

96

Figure 1.

Four types of game design features and eight basic needs

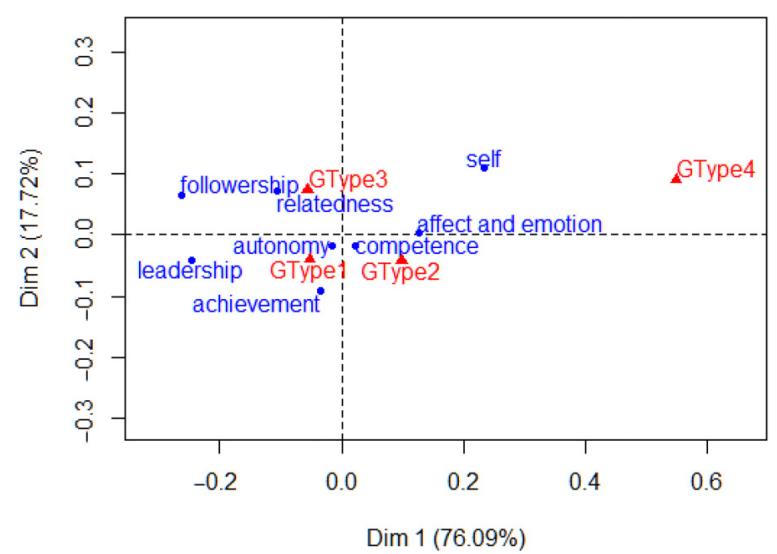

As Type 4 of game design features appeared in only four papers and therefore distant from most of the basic needs, it would be interesting to see the correspondence analysis result with Type 4 being excluded. In this correspondence analysis, the first dimension explained 69 per cent of the variance, and the second dimension explained 30 per cent. The perceptual map (Figure 2) is drawn along these two dimensions. A general observation is that most associations between game feature types and basic needs remain similar to those in Figure 1, but Figure 2 reveals some additional findings. Without Type 4, Type 2 of game design features are close to competence, affect and emotion and self needs. Leadership and followership needs are more closely associated with Type 1 of game design features. Certain needs that are highly conceptually related, such as leadership and followership, competence and achievement and autonomy and self, are not necessarily co-studied as frequently as with other needs.

\section{Discussions}

It is notable that authors of each of the selected papers have their own research agendas and

objectives, and these are not necessarily aligned with a motivational perspective or targeting

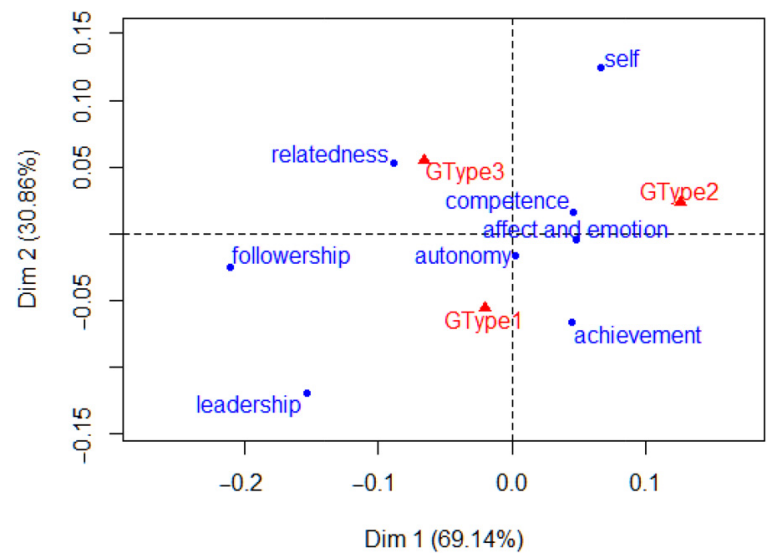

Figure 2.

Three types of game design features and eight basic needs 
on satisfying basic human needs. Therefore, these articles and their authors are not being criticized here for any limitations per se. That being said, the answer to $R Q 1$ is that the literature did not have an extensive focus between game design features and basic human needs. However, we should also admit that even though prior research did not directly investigate the impact of gamification design from the perspective of basic human needs, our identification of distribution of basic needs indicates that the motivational design perspective is widely used by researchers to understand the influences of gamification design.

To answer $R Q 2$, in this section, we examine additional issues and several potentials to investigate gamification from a motivational perspective. The ultimate goal is to increase dialogues and investigations among gamification researchers and practitioners on what they might consider to make their work more engaging and interesting to participants.

\subsection{Are the eight basic needs appropriate in the context of gamification?}

There are various ways of investigating basic human needs. For example, the selfdetermination theory (SDT) focuses on three basic needs: competence, autonomy and relatedness (Ryan and Deci, 2000). In this study, we used Zhang's (2008a) eight basic needs to map out the gamification studies. The result is promising to show that these eight needs can be a more comprehensive representation of basic human needs in the context of gamification. In particular, each of the eight needs seems to be appropriate and is touched upon by the 60 papers collectively. This may open the door to examine further the theoretical bases for gamification research that go beyond the popular SDT.

\subsection{Could a gamification study cover more basic needs?}

The answer is yes. The highest number of needs being touched upon in one paper is six in our pool of literature. Furthermore, as shown in Table III, except Type 4 that is limited by the number of papers selected, all the other three types of game design features have been co-studied with all eight basic needs. Researchers would need to be conscious about the existence of basic needs when investigating the motivational influences of game design features. It is also very challenging to pinpoint associations between specific design features with individual basic needs. Therefore, further research should carefully review and develop the potential theoretical relationships among game design features and basic human needs.

\subsection{What can happen in a study if researchers are conscious about basic needs?}

To be mindful about basic human need might lead to a set of interesting discoveries in research. Satisfying basic needs alone could have its own right and benefit. It would be interesting to find out what happens once basic needs are satisfied. Many of the studies in the literature focus on learning outcomes, task performance and positive attitudes when participants are engaged in gamification. These outcomes might be directly caused by the satisfaction (or lack of) of the basic needs.

\subsection{Could motivational affordance theory prescribe gamification design?}

None of the 60 papers directly used MAT as their theoretical bases or design principles. Yet, given the fitting of the eight basic needs from MAT, one would speculate that applying the motivational affordances perspective may yield gamified technology that satisfies users' various needs. One potential future research is to build on this literature analysis to examine whether incorporating certain MAT design principles (that correspond to basic needs covered in a study) to the study's design may make a positive difference. Another potential 
future research is to expand MAT to address additional factors. One example of such effort is "situated motivational affordances," which describes opportunities to satisfy motivational needs provided by the relation between the features of an artifact and the abilities of a subject in a given situation (when and how) (Deterding, 2011).

\section{Limitations and conclusion}

Several limitations should be noted before interpreting our analysis results. First, the pool of papers is not as large as we hoped to cover. Additional papers with other types of research methods might provide additional insight. Second, theoretical foundations of the collected articles were not discussed in this research, so this research is limited in terms of analyzing these papers from the authors' theoretical perspectives. Third, this study did not go into more details in each of the selected papers to uncover to what extent some of the basic needs are satisfied or not. This is understandable because not all selected papers focused on basic needs and their satisfaction. It would, however, be very interesting to know what factors (game design features, task characteristics, situations, etc.) might satisfy which basic needs and what are the outcomes of such satisfaction. Last, gamification design is an approach that can be operationalized at different levels of abstraction. This paper focused on the level of gamification objects and analyzed associations between game design features and human basic needs from the lens of motivational affordances. We hope that these limitations can turn into future research directions and efforts. Gamification research is a promising design approach that, when designed mindfully, can tap into satisfying basic human needs and thus attract more engagement and use by intended users. This study provides a glimpse of the literature from a motivational perspective and indicates that such a premise is feasible and deserves more attention from researchers and practitioners.

\section{References}

Adukaite, A., van Zyl, I., Er, S.. and Cantoni, L. (2017), "Teacher perceptions on the use of digital gamified learning in tourism education: the case of South African secondary schools", Computers and Education, Vol. 111, pp. 172-190.

Alabbasi, D. (2017), “Exploring graduate students' perspectives towards using gamification techniques in online learning", Turkish Online Journal of Distance Education, Vol. 18 No. 3, pp. 180-196.

Albuquerque, J., Bittencourt, I.I., Coelho, J.A.P.M. and Silva, A.P. (2017), "Does gender stereotype threat in gamified educational environments cause anxiety? An experimental study", Computers and Education, Vol.115, pp. 161-170.

Auvinen, T., Hakulinen, L. and Malmi, L. (2015), "Increasing students' awareness of their behavior in online learning environments with visualizations and achievement badges", Ieee Transactions on Learning Technologies, Vol. 8 No. 3, pp. 261-273.

Aydin, G. (2015), "Adoption of gamified systems: a study on a social media gamification website", International Journal of Online Marketing, Vol. 5 No. 3, pp. 18-1n/a.

Aydin, G. (2018), "Effect of demographics on use intention of gamified systems", International Journal of Technology and Human Interaction, Vol. 14 No. 1, pp. 1-21.

Bittner, J.V. and Shipper, J. (2014), "Motivational effects and age differences of gamification in product advertising", Journal of Consumer Marketing, Vol. 31 No. 5, pp. 391-400.

Boendermaker, W.J., Boffo, M. and Wiers, R.W. (2015), "Exploring elements of fun to motivate youth to do cognitive bias modification", Games for Health Journal, Vol. 4 No. 6, pp. 434-443.

Borras-Gene, O., Martiñez-nunez, M. and Fidalgo-Blanco, A. (2016), "New challenges for the motivation and learning in engineering education using gamification in MOOC", International Journal of Engineering Education, Vol. 32 No. 1, pp. 501-512. 
Broer, J. and Poeppelbuss, J. (2013), "Gamification - a new phenomenon in IS research?", in 24th Australasian Conference on Information Systems, Melbourne, Australia.

Browne, K., Anand, C. and Gosse, E. (2014), "Gamification and serious game approaches for adult literacy tablet software”, Entertainment Computing, Vol. 5 No. 3, pp. 135-146.

Buckley, P. and Doyle, E. (2017), "Individualising gamification: an investigation of the impact of learning styles and personality traits on the efficacy of gamification using a prediction market", Computers and Education, Vol. 106, pp. 43-55.

Chen, C.H., Liu, G.Z. and Hwang, G.J. (2016), "Interaction between gaming and multistage guiding strategies on students' field trip mobile learning performance and motivation", British Journal of Educational Technology, Vol. 47 No. 6, pp. 1032-1050.

Cheong, C., Filippou, J. and Cheong, F. (2014), "Towards the gamification of learning: investigating student perceptions of game elements", Journal of Information Systems Education, Vol. 25 No. 3, pp. 233-244.

Deterding, S. (2011), "Situated motivational affordances of game elements: a conceptual model", in SIGCHI Conference on Human Factors in Computing Systems 2011, Vancouver, BC, Canada, ACM, New York, NY, 7-12 May.

Ding, L., Kim, C. and Orey, M. (2017), "Studies of student engagement in gamified online discussions", Computers and Education, Vol. 115, pp. 126-142.

Fajiculay, J.R., Parikh, B.T., Wright, C.V. and Sheehan, A.H. (2017), "Student perceptions of digital badges in a drug information and literature evaluation course", Currents in Pharmacy Teaching and Learning, Vol. 9 No. 5, pp. 881-886.

Flatla, D.R., Gutwin, C., Nacke, L.E., Bateman, S. and Mandryk, R.L. (2011), "Calibration games: making calibration tasks enjoyable by adding motivating game elements", in Proceedings of the 24th Annual ACM Symposium on User Interface Software and Technology, ACM, Santa Barbara, CA, 16-19 October, pp. 403-412.

Fotaris, P., Mastoras, T., Leinfellner, R. and Rosunally, Y. (2016), "Climbing up the leaderboard: an empirical study of applying gamification techniques to a computer programming class", Electronic Journal of E-Learning, Vol. 14 No. 2, pp. 94-110.

Frost, R.D., Matta, V. and MacIvor, E. (2015), “Assessing the efficacy of incorporating game dynamics in a learning management system", Journal of Information Systems Education, Vol. 26 No. 1, pp. 59-70.

Glynn, D. (2012), "Correspondence analysis. An exploratory technique for identifying usage patterns", Polysemy and Synonymy. Corpus Methods and Applications in Cognitive Linguistics, pp. 133-180.

Gonzalez, C.S., Gomez, N., Navarro, V., Cairos, M., Quirce, C., Toledo, P. and Marrero-Gordillo, N. (2016), "Learning healthy lifestyles through active videogames, motor games and the gamification of educational activities", Computers in Human Behavior, Vol. 55, pp. 529-551.

Greenacre, M.J. (1984), Theory and Applications of Correspondence Analysis, Academic Press, London.

Hair, J.F., Jr, Black, W.C., Babin, B.J., Anderson, R.E. and Tatham, R.L. (2006), Multivariate Data Analysis, Upper Saddle River, New Jersy.

Hakulinen, L., Auvinen, T. and Korhonen, A. (2015), "The effect of achievement badges on students' behavior: an empirical study in a university-level computer science course", International Journal of Emerging Technologies in Learning (Ijet), Vol. 10 No. 1, pp. 18-29.

Halan, S., Rossen, B., Cendan, J. and Lok, B. (2010), "High score! - Motivation strategies for user participation in virtual human development”, Iva, Vol., No. pp. 482-488.

Halloluwa, T., Vyas, D., Usoof, H., Hewagamage, K.P. and Sahama, T. (2016), "Gamifying mathematics for primary students in rural Sri Lanka”, in ACM International Conference Proceeding Series. 
IJCS

3,1

Hamari, J. (2013), "Transforming homo economicus into homo ludens: a field experiment on gamification in a utilitarian peer-to-peer trading service", Electronic Commerce Research and Applications, Vol. 12 No. 4, pp. 236-245.

Hamari, J. and Koivisto, J. (2015a), “Why do people use gamification services?”, International Journal of Information Management, Vol. 35 No. 4, pp. 419-431.

Hamari, J. and Koivisto, J. (2015b), “Working out for likes': an empirical study on social influence in exercise gamification”, Computers in Human Behavior, Vol. 50, pp. 333-347.

Hamari, J., Koivisto, J. and Sarsa, H. (2014), "Does gamification work?-a literature review of empirical studies on gamification", in 47th HI International Conference on System Sciences (HICSS), IEEE, pp. 3025-3034.

Hamzah, W., Ali, N.H., Saman, M.Y.M., Yusoff, M.H. and Yacob, A. (2015a), "Influence of gamification on students' motivation in using e-learning applications based on the motivational design model", International Journal of Emerging Technologies in Learning (jet), Vol. 10 No. 2, pp. 30-34.

Hamzah, W.M.A.F.W., Ali, N.H., Mohd Yusoff, M.H., Yusoff, M.H. and Yacob, A. (2015b), "Enhancement of the ARCS model for gamification of learning", in Proceedings - 2014 3rd International Conference on User Science and Engineering: Experience. Engineer. Engage, $i$ USEr 2014, pp. 287-291.

Hanus, M.D. and Fox, J. (2015), "Assessing the effects of gamification in the classroom: a longitudinal study on intrinsic motivation, social comparison, satisfaction, effort, and academic performance", Computers and Education, Vol. 80, pp. 152-161.

Hew, K.F., Huang, B., Chu, K.W.S. and Chiu, D.K. (2016), "Engaging asian students through game mechanics: findings from two experiment studies", Computers and Education, Vol. 92, pp. 221-236.

Hoffman, D.L. and Franke, G.R. (1986), "Correspondence analysis: graphical representation of categorical data in marketing research", Journal of Marketing Research (JMR), Vol. 23 No. 3, pp. 213-227.

Huotari, K. and Hamari, J. (2017), "A definition for gamification: anchoring gamification in the service marketing literature", Electronic Markets, Vol. 27 No. 1, pp. 21-31.

Iaremenko, N.V. (2017), "Enhancing english language learners' motivation through online games", Information Technologies and Learning Tools, Vol. 59 No. 3, pp. 126-133.

Ipeirotis, P.G. and Gabrilovich, E. (2015), "Quizz:targeted crowdsourcing with a billion (potential) users", in International Conference on World Wide Web, pp. 143-154.

Kaczmarek, L.D., Misiak, M., Behnke, M., Dziekan, M. and Guzik, P. (2017), "The pikachu effect: social and health gaming motivations lead to greater benefits of pokémon GO use", Computers in Human Behavior, Vol. 75, pp. 356-363.

Kim, K. and Ahn, S.J.G. (2017), "The role of gamification in enhancing intrinsic motivation to use a loyalty program", Journal of Interactive Marketing, Vol. 40, pp. 41-51.

Koivisto, J. and Hamari, J. (2014), "Demographic differences in perceived benefits from gamification”, Computers in Human Behavior, Vol. 35, pp. 179-188.

Kwon, K.H., Halavais, A. and Havener, S. (2015), "Tweeting badges: user motivations for displaying achievement in publicly networked environments", Cyberpsychology Behavior and Social Networking, Vol. 18 No. 2, pp. 93-100.

Landers, R.N. and Armstrong, M.B. (2017), "Enhancing instructional outcomes with gamification: an empirical test of the technology-enhanced training effectiveness model", Computers in Human Behavior, Vol. 71, pp. 499-507.

Landers, R.N., Bauer, K.N. and Callan, R.C. (2017), "Gamification of task performance with leaderboards: a goal setting experiment”, Computers in Human Behavior, Vol. 71, pp. 508-515. 
Lee, T.Y., Dugan, C., Geyer, W., Ratchford, T., Rasmussen, J., Shami, N.S. and Lupushor, S. (2013), "Experiments on motivational feedback for crowdsourced workers", in Seventh International AAAI Conference on Weblogs and Social Media, pp. 341-350.

Liu, D., Santhanam, R. and Webster, J. (2017), "Towards meaningful engagement: a framework for design and research of gamified information systems", MIS Quarterly, Vol. 41 No. 4, pp. 1011-1034.

Luu, S. and Narayan, A. (2017), "Games at work: examining a model of team effectiveness in an interdependent gaming task", Computers in Human Behavior, Vol. 77, pp. 110-120.

Malas, R.I. and Hamtini, T.M. (2016), "A gamified e-learning design model to promote and improve learning”, International Review on Computers and Software (Irecos), Vol. 11 No. 1, pp. 8-19.

Massung, E., Coyle, D., Cater, K.F., Jay, M. and Preist, C. (2003), "Using crowdsourcing to support proenvironmental community activism", in CHI 2013 ACM SIGCHI Conference on Human Factors in Computing Systems, pp. 371-380.

Mekler, E.D., Bruhlmann, F., Tuch, A.N. and Opwis, K. (2017), "Towards understanding the effects of individual gamification elements on intrinsic motivation and performance", Computers in Human Behavior, Vol. 71, pp. 525-534.

Morillas Barrio, C., Munoz-Organero, M. and Sanchez Soriano, J. (2016), "Can gamification improve the benefits of student response systems in learning? An experimental study", IEEE Transactions on Emerging Topics in Computing, Vol. 4 No. 3, pp. 429-438.

Morschheuser, B., Hamari, J., Koivisto, J. and Maedche, A. (2017), "Gamified crowdsourcing: Conceptualization, literature review, and future agenda", International Journal of HumanComputer Studies, Vol. 106, pp. 26-43.

Nebel, S., Beege, M., Schneider, S. and Rey, G.D. (2016), "The higher the score, the higher the learning outcome? Heterogeneous impacts of leaderboards and choice within educational videogames", Computers in Human Behavior, Vol. 65, pp. 391-401.

Nebel, S., Schneider, S., Beege, M. and Rey, G.D. (2017), "Leaderboards within educational videogames: the impact of difficulty, effort and gameplay", Computers and Education, Vol. 113, pp. $28-41$.

Nelson, E.C., Verhagen, T. and Noordzij, M.L. (2016), "Health empowerment through activity trackers: an empirical smart wristband study", Computers in Human Behavior, Vol. 62, pp. 364-374.

Peng, W., Lin, J.-H., Pfeiffer, K.A. and Winn, B. (2012), "Need satisfaction supportive game features as motivational determinants: an experimental study of a self-determination theory guided exergame”, Media Psychology, Vol. 15 No. 2, pp. 175-196.

Pe-Than, E.P.P., Goh, D.H.-L. and Lee, C.S. (2014), "Making work fun: investigating antecedents of perceived enjoyment in human computation games for information sharing", Computers in Human Behavior, Vol. 39, pp. 88-99.

Pitura, J. and Chmielarz, D. (2017), "Creating a comic strip is very creative and thanks to it we learn and remember - student perceptions of a biology challenge in a gamified extracurricular CLIL project”, Teaching English with Technology, Vol. 17 No. 3, pp. 77-95.

Preist, C., Massung, E. and Coyle, D. (2014), "Competing or aiming to be average? Normification as a means of engaging digital volunteers", in ACM Conference on Computer Supported Cooperative Work and Social Computing, pp. 1222-1233.

Prestopnik, N.R. and Tang, J. (2015), "Points, stories, worlds, and diegesis: comparing player experiences in two citizen science games", Computers in Human Behavior, Vol. 52, pp. 492-506.

R Development Core Team (2012), R: A Language and Environment for Statistical Computing, $R$ Foundation for Statistical Computing: Vienna, Austria [Online], available at: www.R-project.org [Accessed].

Reeve, J. (2005), Understanding Motivation and Emotion, John Wiley and Sons Inc, New York, NY.

Remenyi, D. (1992), "Researching information systems: data analysis methodology using content and correspondence analysis", Journal of Information Technology, Vol. 7 No. 2, pp. 75-90. 
IJCS
3,1

Rodrigues, L.F., Costa, C.J. and Oliveira, A. (2017), "How does the web game design influence the behavior of e-banking users?”, Computers in Human Behavior, Vol. 74, pp. 163-174.

Rodrigues, L.F., Oliveira, A. and Costa, C.J. (2016a), "Does ease-of-use contributes to the perception of enjoyment? A case of gamification in e-banking", Computers in Human Behavior, Vol. 61, pp. 114-126.

Rodrigues, L.F., Oliveira, A. and Costa, C.J. (2016b), "Playing seriously - how gamification and social cues influence bank customers to use gamified e-business applications", Computers in Human Behavior, Vol. 63, pp. 392-407.

Ryan, R.M. and Deci, E.L. (2000), "Intrinsic and extrinsic motivations: classic definitions and new directions", Contemporary Educational Psychology, Vol. 25 No. 1, pp. 54-67.

Sailer, M., Hense, J.U., Mayr, S.K. and Mandl, H. (2017), "How gamification motivates: an experimental study of the effects of specific game design elements on psychological need satisfaction", Computers in Human Behavior, Vol. 69, pp. 371-380.

Santhanam, R., Liu, D. and Shen, W.C.M. (2016), "Gamification of technology-mediated training: not all competitions are the same", Information Systems Research, Vol. 27 No. 2, pp. 453-465.

Schlagenhaufer, C. and Amberg, M. (2015), "A descriptive literature review and classification framework for gamification in information systems", in 32rd European Conference on Information Systems (ECIS), Münster, Germany.

Siemens, J.C., Smith, S., Fisher, D., Thyroff, A. and Killian, G. (2015), "Level up! The role of progress feedback type for encouraging intrinsic motivation and positive brand attitudes in public versus private gaming contexts", Journal of Interactive Marketing, Vol. 32, pp. 1-12.

Sigala, M. (2015a), "The application and impact of gamification funware on trip planning and experiences: the case of TripAdvisor's funware", Electronic Markets, Vol. 25 No. 3, pp. 189-209.

Sigala, M. (2015b), "The application and impact of gamification funware on trip planning and experiences: the case of TripAdvisor's funware”, Electronic Markets, Vol. 25 No. 3, pp. 189-209.

Snow, E.L., Allen, L.K., Jackson, G.T. and McNamara, D.S. (2015), "Spendency: students' propensity to use system currency", International Journal of Artificial Intelligence in Education, Vol. 25 No. 3, pp. 407-427.

Song, D.L., Ju, P. and Xu, H. (2017), "Engaged cohorts: can gamification engage all college students in class?" Eurasia Journal of Mathematics Science and Technology Education, Vol. 13 No. 7, pp. 3723-3734.

Su, C.H. (2016), "The effects of students' motivation, cognitive load and learning anxiety in gamification software engineering education: a structural equation modeling study", Multimedia Tools and Applications, Vol. 75 No. 16, pp. 10013-10036.

$\mathrm{Su}$, C.H. (2017), "The effects of students' learning anxiety and motivation on the learning achievement in the activity theory based gamified learning environment", Eurasia Journal of Mathematics, Science and Technology Education, Vol. 13 No. 5, pp. 1229-1258.

$\mathrm{Su}$, C.H. and Cheng, C.H. (2015), "A mobile gamification learning system for improving the learning motivation and achievements", Journal of Computer Assisted Learning, Vol. 31 No. 3, pp. 268-286.

Suh, A. and Wagner, C. (2017), "How gamification of an enterprise collaboration system increases knowledge contribution: an affordance approach", Journal of Knowledge Management, Vol. 21 No. 2, pp. 416-431.

Suh, A., Cheung, C.M.K., Ahuja, M. and Wagner, C. (2017), "Gamification in the workplace: the Central role of the aesthetic experience", Journal of Management Information Systems, Vol. 34 No. 1, pp. 268-305.

Tan, M. and Hew, K.F. (2016), "Incorporating meaningful gamification in a blended learning research methods class: examining student learning, engagement, and affective outcomes", Australasian Journal of Educational Technology, Vol. 32 No. 5, pp. 19-34. 
Wang, J.H., Chen, S.Y. and Chan, T.W. (2016), “An investigation of a joyful peer response system: High ability vs low ability", International Journal of Human-Computer Interaction, Vol. 32 No. 6, pp. 431-444.

Yang, Y., Asaad, Y. and Dwivedi, Y. (2017), "Examining the impact of gamification on intention of engagement and brand attitude in the marketing context", Computers in Human Behavior, Vol. 73, pp. 459-469.

Zarzycka-Piskorz, E. (2016), "Kahoot it or not? Can games be motivating in learning grammar?", Teaching English with Technology, Vol. 16 No. 3, pp. 17-36.

Zhang, P. (2008a), "Motivational affordances: fundamental reasons for ICT design and use", Communications of the Acm, Vol. 51 No. 11, pp. 145-147.

Zhang, P. (2008b), "Toward a positive design theory: Principles for designing motivating information and communication technology", Avital, M., Bolland, R. and Cooperrider, D. (Eds), Designing Information and Organizations with a Positive Lens, Emerald Group Publishing Limited, San Diego, CA.

\section{Corresponding author}

Jian Tang can be contacted at: jiantang@cufe.edu.cn

For instructions on how to order reprints of this article, please visit our website: 